\title{
A comparative study of the metabolic response in rainbow trout and Nile tilapia to changes in dietary macronutrient composition
}

\author{
A. Cláudia Figueiredo-Silva ${ }^{1}$, Subramanian Saravanan ${ }^{2}$, Johan W. Schrama ${ }^{2}$, Stéphane Panserat ${ }^{1}$, \\ Sadasivam Kaushik ${ }^{1}$ and Inge Geurden ${ }^{1 *}$ \\ ${ }^{1}$ INRA, UR1067, Nutrition, Metabolism and Aquaculture, Pôle d'Hydrobiologie INRA, F-64310 Saint Pée-sur-Nivelle, \\ France \\ ${ }^{2}$ Aquaculture and Fisheries Group, Wageningen University, PO Box 338, 6700 AH Wageningen, The Netherlands
}

(Submitted 11 January 2012 - Final revision received 16 April 2012 - Accepted 17 April 2012 - First published online 24 July 2012)

\begin{abstract}
Metabolic mechanisms underlying the divergent response of rainbow trout (Oncorhynchus mykiss) and Nile tilapia (Oreochromis niloticus) to changes in dietary macronutrient composition were assessed. Fish were fed one of four isoenergetic diets having a digestible proteinto-digestible energy (DP:DE) ratio above or below the optimal DP:DE ratio for both species. At each DP:DE ratio, fat was substituted by an isoenergetic amount of digestible starch as the non-protein energy source (NPE). Dietary DP:DE ratio did not affect growth and only slightly lowered protein gains in tilapia. In rainbow trout fed diets with low DP:DE ratios, particularly with starch as the major NPE source, growth and protein utilisation were highly reduced, underlining the importance of NPE source in this species. We also observed species-specific responses of enzymes involved in amino acid catabolism, lipogenesis and gluconeogenesis to dietary factors. Amino acid transdeamination enzyme activities were reduced by a low dietary DP:DE ratio in both species and in tilapia also by the substitution of fat by starch as the NPE source. Such decreased amino acid catabolism at high starch intakes, however, did not lead to improved protein retention. Our data further suggest that a combination of increased lipogenic and decreased gluconeogenic enzyme activities accounts for the better use of carbohydrates and to the improved glycaemia control in tilapia compared with rainbow tront fed starch-enriched diets with low DP:DE ratio.
\end{abstract}

Key words: Digestible protein/digestible energy: Non-protein energy: Nutrient utilisation: Hepatic enzyme activity: Glycaemia

Recommended dietary macronutrient levels differ among teleosts $^{(1)}$. Optimal levels of digestible protein (DP) and digestible non-protein energy (NPE; fat or starch) are often related to the species' trophic level or feeding habitat. Dietary protein levels for maximum growth of fish depend also on the digestible energy (DE) level or DP:DE ratio, and hence on the amount of NPE in the $\operatorname{diet}^{(2)}$. Studies on the effect of dietary NPE on growth and nutrient utilisation mostly focused on total NPE levels ${ }^{(3-8)}$, despite clear evidence that the protein-sparing effect of digestible fat and carbohydrates is species-dependent, varying according to species' feeding habitat (cold $v$. warm-water) or feeding habit (carnivorous $v$. omnivorous) ${ }^{(9-13)}$. For example, while rainbow trout or other salmonids efficiently utilise dietary lipid above $10 \%$ without negative effects on growth ${ }^{(13-15)}$, other fish species such as turbot, Senegalese sole, Nile tilapia and grass carp seem to display a limited ability to use high dietary fat ${ }^{(16-22)}$. On the other hand, most warm-water fish such as Nile tilapia appear to utilise higher levels (up to $40 \%$ of diet DM) of dietary carbohydrates than cold-water fish such as rainbow trout $(\leq 20 \%$ of diet $\mathrm{DM})^{(1,10,23,24)}$. The limited ability of rainbow trout (carnivorous-like species) compared to, for example, Nile tilapia and common carp (omnivorous-like species) to efficiently utilise dietary carbohydrates as a NPE source is illustrated by the prolonged hyperglycaemia after oral administration of glucose or high-carbohydrate meals $(>20 \%$ of diet DM) in the former ${ }^{(25-27)}$. Similar induction of enzyme activity or gene expression of glucose-phosphorylating enzymes by dietary carbohydrates in the liver of rainbow trout and common carp $^{(28)}$, however, suggests that metabolic mechanisms other

Abbreviations: ALAT, alanine aminotransferase; ASAT, aspartate aminotransferase; DE, digestible energy; DP, digestible protein; FAS, fatty acid synthase; G6Pase, glucose-6-phosphatase; G6PD, glucose-6-phosphate dehydrogenase; GDH, glutamate dehydrogenase; GK, glucokinase; HK, hexokinase; HOAD, 3-hydroxyacyl-CoA dehydrogenase; HPF, high protein with fat as the major non-protein energy source; HPS, high protein with starch as the major non-protein energy source; LPF, low protein with fat as the major non-protein energy source; LPS, low protein with starch as the major non-protein energy source; ME, malic enzyme; NPE, non-protein energy.

* Corresponding author: I. Geurden, fax + 33 559545152, email geurden@st-pee.inra.fr 
than glycolysis per se are implicated in the control of dietary glucose utilisation. Yet, surprisingly few studies have compared, by using identical diet formulations, possible metabolic mechanisms underlying differences in macronutrient utilisation between different fish species.

The present study aims to highlight divergences between two teleosts, rainbow trout and Nile tilapia, in the response of intermediary metabolism to changes in dietary DP:DE ratio and in NPE source. To this purpose, four isoenergetic diets were formulated with a DP:DE ratio above $(27 \mathrm{mg} / \mathrm{kJ})$ and below $(14 \mathrm{mg} / \mathrm{kJ})$ the optimal DP:DE ratio for both tilapia $^{(1,29)}$ and rainbow trout ${ }^{(1,30)}$. At each dietary DP:DE ratio, a contrast was created in the NPE source by replacing fat by an isoenergetic amount of digestible starch. The diet-induced responses of rainbow trout and Nile tilapia in terms of nutrient gain and utilisation were then associated with data on circulating plasma metabolites and activity levels of key enzymes involved in hepatic intermediary metabolism.

\section{Materials and methods}

\section{Fish, feed and growth trial}

The feeding trial with rainbow trout was conducted following the Guidelines of the National Legislation on Animal Care of the French Ministry of Research (Décret no. 2001-464 of May 29, 2001). All procedures involving Nile tilapia were carried out in accordance with the Dutch law on experimental animals and were approved by the Wageningen University Animal Experimental Committee (DEC). Details on the feeding and digestibility trials of the fish used in this study have been described previously for rainbow trout ${ }^{(31)}$ and tilapia ${ }^{(32)}$, with specific focus on the regulation of diet-induced differences in voluntary feed intake as a function of dietary energy use. Briefly, four isoenergetic (approximately $18.5 \mathrm{MJ} \mathrm{DE} / \mathrm{kg}$ diet DM) diets $(2 \times 2$ factorial design) were formulated (Table 1$)$ having a contrast in (i) the ratio of DP:DE: high (HP, approximately $27 \mathrm{mg} / \mathrm{kJ}$ ) or low (LP, approximately $14 \mathrm{mg} / \mathrm{kJ}$ ) and (ii) the type of NPE source: fat (F) $v$. starch (S) which were isoenergetically exchanged. We thus had four experimental diets that were expected to exacerbate differences in metabolic response, having a high DP:DE ratio with fat (HPF) or starch (HPS) as the NPE source or a low DP:DE ratio with fat (LPF) or starch (LPS) as the NPE source (Table 1). Inclusion of $15 \%$ of cellulose as indigestible filler to the F-diets allowed an identical nutrient and energy density between diets. The diets were carefully fed by hand to apparent visual satiation to triplicate groups of rainbow trout (initial body mass $32 \mathrm{~g}$; $17^{\circ} \mathrm{C}$; INRA Donzacq experimental fish farm, France) and Nile tilapia (initial body mass $40 \mathrm{~g} ; 28^{\circ} \mathrm{C}$; Wageningen University, The Netherlands) for 42 and $48 \mathrm{~d}$, respectively. At the end of the feeding trial, the liver (nine fish/treatment) was dissected at $7 \mathrm{~h}$ after the last meal in rainbow trout and $3 \mathrm{~h}$ after the last meal in Nile tilapia and immediately stored at $-80^{\circ} \mathrm{C}$ for subsequent analyses of enzyme activities. Blood samples (nine fish/treatment) were collected at 7 and $40 \mathrm{~h}$ after the meal in trout and at 3 and $36 \mathrm{~h}$ after the meal in tilapia. Postprandial sampling times were selected to represent the time at which plasma metabolites are found to peak and return to basal levels in the respective species (our own

Table 1. Ingredient and analysed composition of the diets fed to rainbow trout and Nile tilapia

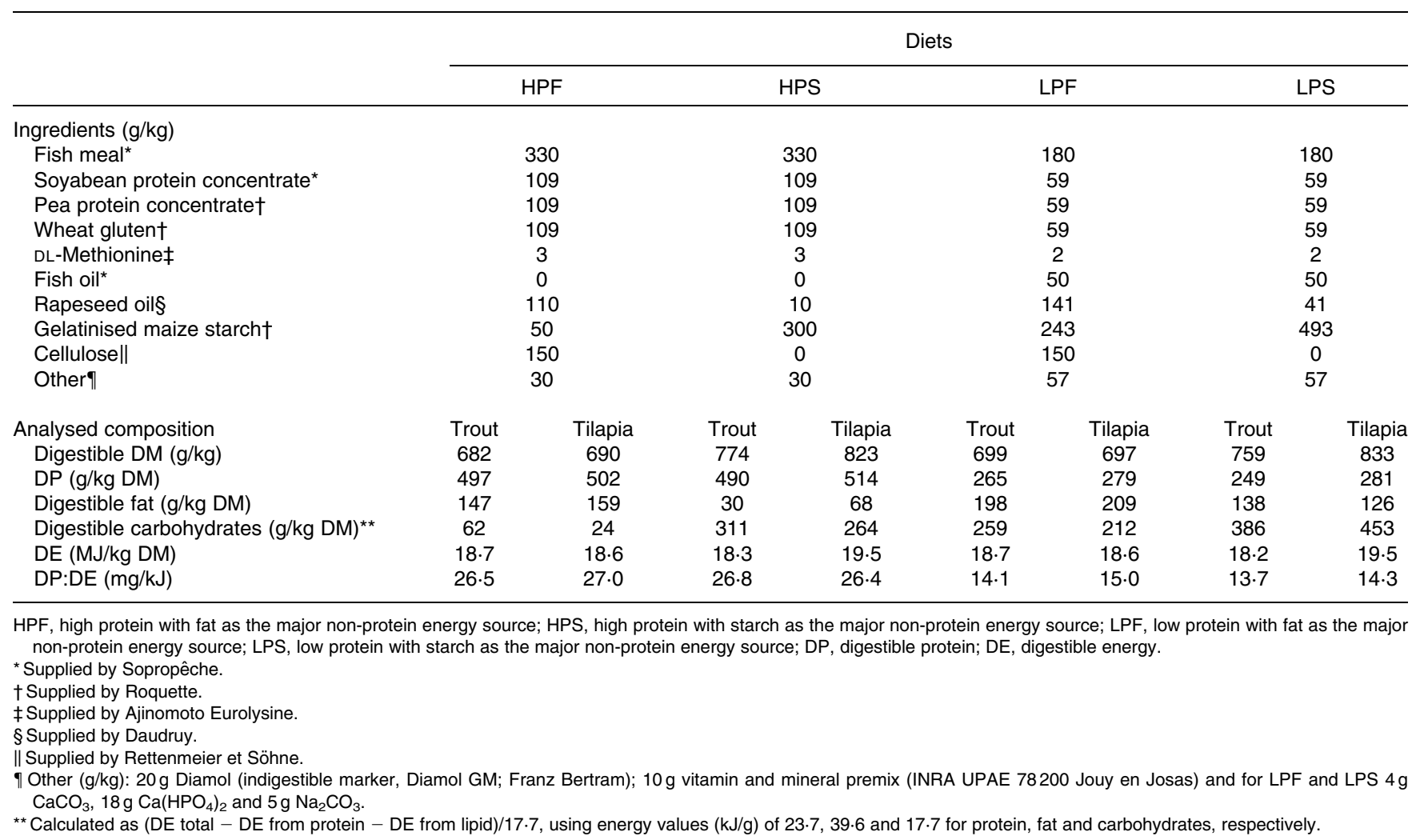


observation). Blood samples were taken from the caudal vein and collected into tubes using sodium fluoride (2\%) and potassium oxalate ( $4 \%$ ) as anti-coagulant. Plasma samples, obtained after centrifugation $\left(3000 \mathrm{~g}\right.$ for $15 \mathrm{~min}$ at $4^{\circ} \mathrm{C}$ ), were stored at $-20^{\circ} \mathrm{C}$ for further analyses.

\section{Feed, whole-body and plasma metabolite analyses}

Feed and whole-body analyses were made as detailed previously for rainbow trout ${ }^{(31)}$ and Nile tilapia ${ }^{(32)}$. Plasma glucose and TAG were determined as described previously ${ }^{(31)}$. For the determination of total plasma free amino acids, samples were treated by ultra-filtration to eliminate protein, with a centrifugation at $2000 \mathrm{~g}$ for $2 \mathrm{~h}$ followed by filtration (filters Amicon-Microcon, YM $100000 \mathrm{Da}$ ). Next, $500 \mu \mathrm{l}$ of water and $300 \mu \mathrm{l}$ of ninhydrine reagent ( $2 \%$ solution; Sigma) were added to $100 \mu \mathrm{l}$ of filtrate and left for $10 \mathrm{~min}$ at $100^{\circ} \mathrm{C}$. Then, $1.5 \mathrm{ml}$ of ethanol were added progressively to stop the reaction. After $30 \mathrm{~min}$ in the dark, absorbance was measured at $570 \mathrm{~nm}$ using a spectrophotometer (Shimadzu UV-160A; Shimadzu Scientific Instruments). Results are expressed in $\mu \mathrm{mol} / \mathrm{ml}$ of plasma.

\section{Enzyme activity measurement}

Activities of alanine aminotransferase (ALAT, EC 2.6.1.2), aspartate aminotransferase (ASAT; EC 2.6.1.1), glutamate dehydrogenase (GDH, EC 1.4.1.2), glucose-6-phosphate dehydrogenase (G6PD, EC 1.1.1.49), malic enzyme (ME, EC 1.1.1.40), fatty acid synthase (FAS, EC 2.3.1.38), hexokinase (HK; EC 2.7.1.1) and glucokinase (GK, $E C$ 2.7.1.2) were determined in rainbow trout and Nile tilapia liver as described previously ${ }^{(33)}$. Activity of GK was corrected by measuring glucose dehydrogenase activity (EC 1.1.1.47), a moderately active microsomal enzyme in fish liver that can introduce significant bias into GK measurements on frozen tissue ${ }^{(34)}$. To measure glucose-6-phosphatase (G6Pase; EC 3.1.3.9) activity, the liver microsomal fraction was suspended in buffer $\left(100 \mathrm{~mm}-\mathrm{NaH}_{2} \mathrm{PO}_{4} ; 25 \mathrm{~mm}-\right.$ $\mathrm{Na}_{2} \mathrm{HPO}_{4} ; 2 \mathrm{~mm}$-EDTA; 1mm-dithiothreitol (DTT), $\mathrm{pH}$ 7) and G6Pase assayed according to Panserat et $a l^{(35)}$. Activity of 3-hydroxyacyl-CoA dehydrogenase (HOAD, EC 1.1.1.35) was determined as described previously ${ }^{(36)}$. Enzyme activity (units IU), defined as $\mu$ mol of substrate converted to product per min at assay temperature, was expressed per mg of soluble protein (specific activity). Soluble protein content (Bradford method) was determined using a protein assay kit (Bio-Rad) and bovine serum albumin as a standard.

\section{Statistical analysis}

Statistical analyses were performed using the STATISTICS 7.0 package (StatSoft, Inc.). All data were tested for normality and homogeneity of variances by Kolmogorov-Smirnov and Bartlett tests, and then submitted to a two-way ANOVA, using dietary DP:DE and NPE as independent factors. When the interaction between DP:DE and NPE was significant $(P<0 \cdot 05)$, individual means were compared using the Tukey honest significant difference test. Pearson correlation coefficients $(R)$ were obtained by the Pearson product moment correlation distribution and considered significant when $P<0 \cdot 05$.

\section{Results}

Table 2 summarises the data on food intake and growth performances for both rainbow trout and Nile tilapia. Data on total food intake, initial and final body mass and efficiency of nutrient retention have been presented before for trout ${ }^{(31)}$ and for tilapia ${ }^{(32)}$. At the end of the 42- and 48-d feeding trial, trout exhibited a 2- to 3-fold and tilapia a 5- to 6-fold increase in body mass (Table 2). The thermal growth coefficients obtained with the high-DP:DE diets were similar for tilapia $(1 \cdot 9-2 \cdot 1)$ and trout $(2 \cdot 0-2 \cdot 1)$. Thermal growth coefficients of trout were affected by both the DP:DE ratio and NPE source, with a significant interaction between both; replacement of fat by digestible starch significantly reduced thermal growth coefficients of trout at low but not at high DP:DE (Table 2). Thermal growth coefficients of tilapia were reduced by the replacement of fat by digestible starch, but not by the dietary DP:DE ratio (Table 2).

In both species, diet-induced differences in daily protein gains generally associated well with growth, with the exception of the low protein gains at low DP:DE in tilapia (Table 2). Protein and lipid retention efficiencies (Table 2) were expressed per unit digestible nutrient intakes in order to correct for the possible effects of cellulose on nutrient uptakes. Feeding diets with a low $v$. high DP:DE ratio almost doubled protein utilisation efficiency (protein gain per unit DP intake) in tilapia (from $37 \%$ to over 59\%), independent of the NPE source. Protein retention efficiency in trout fed the low-DP:DE diets was lower than in tilapia and was only improved with fat and not starch as the major NPE source (44 and 34\%, respectively, Table 2).

The amount of lipid deposited per unit protein accretion was generally higher in tilapia than in trout (Table 2). The reduction of the DP:DE ratio (from approximately 27 to approximately $14 \mathrm{mg} / \mathrm{kJ}$ ) and the addition of fat as the NPE source increased lipid deposition in both species (Table 2). Diet-induced changes in lipid retention efficiency (lipid gain per unit digestible lipid intake), being highly enhanced by the replacement of fat by starch, were comparable between both species at high DP:DE (>200\%, Table 2). In contrast, both species displayed a distinct response when fed the low-DP:DE diets. Here, the replacement of fat by starch enhanced lipid retention in tilapia (150 v. 98\%, with diet LPS $v$. LPF) but not in trout (67-68\% with both diets LPS and LPF, Table 2).

Table 3 compares the effect of dietary macronutrient composition on plasma levels of free amino acids, glucose and TAG in trout ( 7 and $40 \mathrm{~h}$ ) and tilapia ( 3 and $36 \mathrm{~h}$ ). Postprandial plasma free amino acid levels reflected DP levels in both species without significant effect of NPE source. Postprandial plasma glucose levels increased in both species following the reduction of DP:DE and the replacement of fat by starch. This effect was more pronounced in trout than in tilapia and was still visible in $40 \mathrm{~h}$ feed-deprived trout but not in $36 \mathrm{~h}$ feed-deprived tilapia. In trout, postprandial glycaemia 
Table 2. Growth performance, food intake, digestible nutrient intake, nutrient gain and retention in rainbow trout and Nile tilapia fed diets with different digestible protein-to-energy (DP:DE) ratio and non-protein energy source (NPE, fat $v$. starch) for 6 weeks

(Mean values and standard deviations, $n 3$ )

\begin{tabular}{|c|c|c|c|c|c|c|c|c|c|c|c|}
\hline & \multicolumn{11}{|c|}{ Diets } \\
\hline & \multicolumn{2}{|c|}{ HPF } & \multicolumn{2}{|c|}{ HPS } & \multicolumn{2}{|c|}{ LPF } & \multicolumn{2}{|c|}{ LPS } & \multicolumn{3}{|c|}{$P$} \\
\hline & Mean & SD & Mean & SD & Mean & SD & Mean & SD & DP:DE & NPE & DP:DE $\times N P E$ \\
\hline \multicolumn{12}{|c|}{ Growth performance and food intake } \\
\hline \multicolumn{12}{|l|}{ Rainbow trout } \\
\hline Initial body mass (g) & 32.4 & 0.6 & 32.5 & 0.7 & $32 \cdot 3$ & 0.5 & 32.4 & 0.7 & 0.79 & 0.79 & 1.00 \\
\hline Final body mass $(\mathrm{g})$ & $103 \cdot 7^{\mathrm{a}}$ & 9.0 & $96 \cdot 6^{\mathrm{a}, \mathrm{b}}$ & 4.0 & $84 \cdot 4^{\mathrm{b}}$ & $5 \cdot 0$ & $59 \cdot 5^{\mathrm{c}}$ & $2 \cdot 4$ & $<0.01$ & $<0.01$ & $<0.05$ \\
\hline TGC* & $2 \cdot 1^{\mathrm{a}}$ & 0.2 & $2 \cdot 0^{\mathrm{a}, \mathrm{b}}$ & 0.1 & $1.7^{\mathrm{b}}$ & 0.1 & $1.0^{\mathrm{c}}$ & 0.1 & $<0.01$ & $<0.01$ & $<0.01$ \\
\hline Food intake† & $16 \cdot 6^{\mathrm{a}}$ & 0.2 & $14 \cdot 7^{\mathrm{b}}$ & 0.3 & $15 \cdot 4^{\mathrm{a}, \mathrm{b}}$ & 0.9 & $11.6^{\mathrm{c}}$ & 0.3 & $<0.01$ & $<0.01$ & $<0.01$ \\
\hline Protein intake† & 8.3 & 0.1 & $7 \cdot 2$ & 0.2 & 4.1 & 0.2 & 2.9 & 0.1 & $<0.01$ & $<0.01$ & 0.44 \\
\hline Lipid intake† & $2 \cdot 5^{\mathrm{b}}$ & 0.03 & $0.4^{\mathrm{d}}$ & 0.01 & $3.1^{a}$ & 0.2 & $1.6^{\mathrm{C}}$ & 0.04 & $<0.01$ & $<0.01$ & $<0.01$ \\
\hline Carbohydrate intake $†$ & $1 \cdot 0^{c}$ & 0.01 & $4 \cdot 6^{\mathrm{a}}$ & 0.1 & $4.0^{\mathrm{b}}$ & 0.2 & $4.5^{\mathrm{a}}$ & 0.1 & $<0.01$ & $<0.01$ & $<0.01$ \\
\hline \multicolumn{12}{|l|}{ Nile tilapia } \\
\hline Initial body mass (g) & $40 \cdot 6$ & $1 \cdot 2$ & $40 \cdot 1$ & 0.2 & $40 \cdot 6$ & 0.8 & 41.0 & 1.0 & 0.39 & 0.95 & 0.40 \\
\hline Final body mass (g) & 240.8 & $13 \cdot 1$ & $213 \cdot 7$ & 9.0 & 249.8 & 23.2 & 221.0 & 7.4 & 0.36 & 0.01 & 0.93 \\
\hline TGC* & $2 \cdot 1$ & 0.1 & 1.9 & 0.1 & $2 \cdot 1$ & 0.2 & 1.9 & 0.1 & 0.47 & $<0.05$ & 0.85 \\
\hline Food intake† & 23.4 & 0.6 & 21.5 & 0.5 & $25 \cdot 1$ & $2 \cdot 3$ & $22 \cdot 8$ & 0.8 & 0.07 & $<0.05$ & 0.76 \\
\hline Protein intake† & 11.7 & 0.3 & 11.1 & 0.2 & $7 \cdot 0$ & 0.6 & 6.4 & 0.2 & $<0.01$ & $<0.05$ & 0.91 \\
\hline Lipid intake† & 3.7 & 0.1 & 1.5 & 0.03 & $5 \cdot 2$ & 0.5 & 2.9 & 0.1 & $<0.01$ & $<0.01$ & 0.68 \\
\hline Carbohydrate intake $\dagger$ & 0.6 & 0.01 & 5.7 & 0.1 & $5 \cdot 3$ & 0.5 & $10 \cdot 3$ & 0.4 & $<0.01$ & $<0.01$ & 0.76 \\
\hline \multicolumn{12}{|l|}{ Nutrient gain $\ddagger$} \\
\hline \multicolumn{12}{|l|}{ Rainbow trout } \\
\hline Protein gain & $0.15^{a}$ & 0.01 & $0.15^{\mathrm{a}}$ & 0.004 & $0.11^{\mathrm{b}}$ & 0.01 & $0.06^{c}$ & 0.01 & $<0.01$ & $<0.01$ & $<0.01$ \\
\hline Lipid gain & 0.12 & 0.01 & 0.07 & 0.01 & 0.12 & 0.02 & 0.06 & 0.01 & 0.92 & $<0.01$ & 0.50 \\
\hline Lipid:protein ratio & 0.8 & 0.04 & 0.4 & 0.04 & $1 \cdot 2$ & 0.1 & $1 \cdot 1$ & 0.3 & $<0.01$ & 0.07 & 0.17 \\
\hline \multicolumn{12}{|l|}{ Nile tilapia } \\
\hline Protein gain & 0.14 & 0.004 & 0.14 & 0.01 & 0.14 & 0.01 & 0.12 & 0.004 & $<0.05$ & 0.06 & 0.30 \\
\hline Lipid gain & 0.13 & 0.01 & $0 \cdot 10$ & 0.003 & $0 \cdot 18$ & 0.02 & 0.15 & 0.01 & $<0.01$ & $<0.01$ & 0.81 \\
\hline Lipid:protein ratio & 0.9 & 0.1 & 0.7 & 0.02 & 1.3 & 0.1 & 1.2 & 0.1 & $<0.01$ & $<0.01$ & 0.39 \\
\hline \multicolumn{12}{|c|}{ Nutrient retention efficiency (\% digestible nutrient intake) } \\
\hline \multicolumn{12}{|c|}{ Rainbow trout } \\
\hline Protein & $31.6^{\mathrm{b}}$ & 2.5 & $35.4^{\mathrm{b}}$ & 1.5 & $44.0^{\mathrm{a}}$ & $2 \cdot 1$ & $34.1^{\mathrm{b}}$ & $4 \cdot 0$ & $<0.01$ & 0.08 & $<0.01$ \\
\hline Lipid & $82 \cdot 2^{\mathrm{b}}$ & 3.2 & $254 \cdot 3^{\mathrm{a}}$ & $15 \cdot 8$ & $68 \cdot 2^{\mathrm{b}}$ & 4.7 & $66 \cdot 9^{b}$ & 11.3 & $<0.01$ & $<0.01$ & $<0.01$ \\
\hline \multicolumn{12}{|l|}{ Nile tilapia } \\
\hline Protein & $36 \cdot 0$ & 0.2 & 38.0 & 1.5 & 58.0 & $1 \cdot 1$ & 59.0 & 0.2 & $<0.01$ & 0.71 & 0.19 \\
\hline Lipid & $98.0^{\mathrm{C}}$ & 7.9 & $201 \cdot 1^{a}$ & 3.3 & $97 \cdot 7^{\mathrm{C}}$ & 3.0 & $150 \cdot 4^{\mathrm{b}}$ & $7 \cdot 3$ & $<0.01$ & $<0.01$ & $<0.01$ \\
\hline
\end{tabular}

HPF, high protein with fat as the major NPE; HPS, high protein with starch as the major NPE; LPF, low protein with fat as the major NPE; LPS, low protein with starch as the major NPE; TGC, thermal growth coefficients; MBW, metabolic body weight.

作

${ }^{*} \mathrm{TGC}=1000 \times(\text { (final body mass })^{1 / 3}-$ (initial body mass $\left.)^{1 / 3}\right) /\left(\right.$ temperature $\left({ }^{\circ} \mathrm{C}\right) \times$ number of $\left.\mathrm{d}\right)$

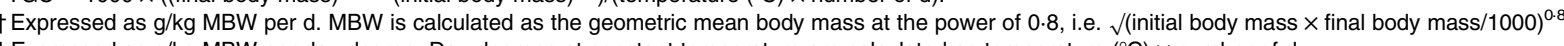

$\ddagger$ Expressed as $\mathrm{g} / \mathrm{kg} \mathrm{MBW}$ per day-degree. Day-degrees at constant temperature are calculated as temperature $\left({ }^{\circ} \mathrm{C}\right) \times$ number of $\mathrm{d}$. 
Table 3. Levels of plasma metabolites in rainbow trout and Nile tilapia fed diets with different digestible protein-to-energy (DP:DE) ratio and non-protein energy source (NPE, fat $v$. starch) for 6 weeks

(Mean values and standard deviations, $n$ 9)

\begin{tabular}{|c|c|c|c|c|c|c|c|c|c|c|c|}
\hline & \multicolumn{11}{|c|}{ Diets } \\
\hline & \multicolumn{2}{|c|}{ HPF } & \multicolumn{2}{|c|}{ HPS } & \multicolumn{2}{|c|}{ LPF } & \multicolumn{2}{|c|}{ LPS } & \multicolumn{3}{|c|}{$P$} \\
\hline & Mean & SD & Mean & SD & Mean & SD & Mean & SD & DP:DE & NPE & $\mathrm{DP}: \mathrm{DE} \times \mathrm{NPE}$ \\
\hline \multicolumn{12}{|c|}{$\begin{array}{l}\text { Rainbow trout } \\
\text { FAA }(\mu \mathrm{mol} / \mathrm{ml})\end{array}$} \\
\hline $7 \mathrm{~h}$ & $7 \cdot 1$ & 1.5 & $7 \cdot 3$ & $1 \cdot 0$ & $5 \cdot 9$ & 0.7 & $5 \cdot 8$ & 1.5 & $<0.01$ & 0.92 & 0.74 \\
\hline $40 \mathrm{~h}$ & 4.4 & 0.5 & $4 \cdot 4$ & $0 \cdot 8$ & $4 \cdot 4$ & 0.8 & 4.5 & 0.4 & 0.46 & 0.47 & 0.38 \\
\hline \multicolumn{12}{|c|}{ Glucose (g/l) } \\
\hline $7 \mathrm{~h}$ & $0.74^{c}$ & 0.14 & $0.77^{c}$ & 0.18 & $1.90^{\mathrm{b}}$ & 0.48 & $4.06^{a}$ & 1.0 & $<0.01$ & $<0.01$ & $<0.01$ \\
\hline $40 \mathrm{~h}$ & 0.68 & 0.06 & 0.59 & 0.05 & 1.32 & 0.36 & 0.99 & 0.22 & $<0.01$ & $<0.01$ & $0 \cdot 10$ \\
\hline \multicolumn{12}{|c|}{ TAG $(g / l)$} \\
\hline $7 \mathrm{~h}$ & 5.9 & 1.0 & $4 \cdot 3$ & $1 \cdot 2$ & 5.9 & $2 \cdot 2$ & $4 \cdot 2$ & 1.5 & 0.97 & $<0.01$ & 0.96 \\
\hline $40 \mathrm{~h}$ & $2 \cdot 2$ & 0.8 & 1.6 & 0.5 & $2 \cdot 0$ & 0.7 & 1.1 & 0.4 & 0.11 & $<0.01$ & 0.61 \\
\hline \multicolumn{12}{|c|}{ Nile tilapia } \\
\hline $3 \mathrm{~h}$ & $5 \cdot 4$ & $2 \cdot 7$ & $5 \cdot 7$ & $1 \cdot 3$ & $3 \cdot 4$ & 0.9 & 3.0 & 1.0 & $<0.01$ & 0.99 & 0.61 \\
\hline $36 \mathrm{~h}$ & 2.9 & 0.5 & 3.4 & 0.8 & $2 \cdot 5$ & 0.4 & $2 \cdot 8$ & 0.5 & $<0.01$ & $<0.05$ & 0.50 \\
\hline \multicolumn{12}{|c|}{ Glucose (g/l) } \\
\hline $3 \mathrm{~h}$ & 0.57 & 0.05 & 0.77 & 0.08 & 0.92 & 0.09 & $1 \cdot 15$ & 0.60 & $<0.01$ & $<0.05$ & 0.88 \\
\hline $36 \mathrm{~h}$ & 0.45 & 0.08 & 0.46 & 0.08 & 0.46 & 0.10 & 0.42 & 0.07 & 0.47 & 0.57 & 0.39 \\
\hline \multicolumn{12}{|c|}{ TAG $(g / l)$} \\
\hline $3 \mathrm{~h}$ & $2 \cdot 6^{\mathrm{b}}$ & 1.3 & $3.7^{\mathrm{b}}$ & 1.5 & $6.7^{\mathrm{a}}$ & $2 \cdot 3$ & $3.7^{\mathrm{b}}$ & $2 \cdot 1$ & $<0.01$ & 0.16 & $<0.01$ \\
\hline $36 \mathrm{~h}$ & 1.7 & $1 \cdot 1$ & 1.5 & 0.5 & $2 \cdot 3$ & 1.0 & $2 \cdot 2$ & 1.3 & $<0.05$ & 0.68 & 0.74 \\
\hline
\end{tabular}

showed a significant interaction between DP:DE and NPE, being markedly higher with diet LPS. In tilapia, no interaction was noted between both factors on glycaemia. Diets containing fat as the NPE increased plasma TAG levels in both species, this effect being highly pronounced in tilapia fed the LPF diet, with an interaction between both dietary factors.

The activity of the selected key enzymes of amino acid catabolism (Fig. 1), lipogenesis and $\beta$-oxidation (Fig. 2), glycolysis and gluconeogenesis (Fig. 3) was analysed in the liver of trout and tilapia, 7 and $3 \mathrm{~h}$ after the meal, respectively. Except for the activity of ASAT, which was higher in tilapia than in trout liver, overall activity levels of ALAT and GDH were similar between both species. The activities of ALAT, ASAT and GDH varied according to differences in DP intakes in both species $(R>0.70 ; P<0.05)$. In addition, ALAT and GDH activities were reduced in tilapia (Fig. 1(B) and (F)) by the replacement of fat by starch and were negatively correlated with digestible carbohydrate intake $(R-0.80 ; P<0.05)$. No such effect of the source of NPE on hepatic transdeamination activities was detected in trout.

The changes in dietary macronutrient composition differently affected hepatic lipogenic enzyme (FAS, ME, G6PD) activities (Fig. 2). In the liver of both species, a significant interaction between DP:DE ratio and NPE source was noted on FAS activities. In trout, FAS activity was higher with diet HPS than with diet HPF and the low-DP:DE diets (Fig. 3(E)). Tilapia also displayed high FAS (Fig. 2(F)) and ME (Fig. 2(B)) activities with diet HPS, which in this species were not different from those found in fish fed the low-DP:DE diets.
ME activities were not affected by diet composition in trout (Fig. 2(A)), whereas those in tilapia (Fig. 2(B)) paralleled FAS activities (Fig. 2(F)). The response of G6PD to changes in macronutrient composition was also species-specific and its activities overall lower in tilapia than in trout (Fig. 2(C) and (D)). The replacement of fat by starch increased G6PD in tilapia (Fig. 2(D)), whereas in trout there was a higher G6PD activity only with diet HPS (Fig. 2(C), interaction between DP:DE and NPE). Species-specific differences in the response of the lipogenic enzyme activities to NPE source were further evidenced by the positive correlation between carbohydrate intake and ME, G6PD and FAS in tilapia $(R>0.75 ; P<0.05)$. This correlation was only seen in trout for G6PD $(R \quad 0.76 ; P<0.05)$ and not for ME $(R-0.16$; $P>0.05)$ or FAS $(R 0.20 ; P>0.05)$. Interestingly, FAS activities were positively correlated with DP intakes in trout $(R 0.66$; $P<0.05)$, but not in tilapia $(R-0.54 ; P>0.05)$ and negatively correlated with digestible lipid intakes in trout $(R-0.77$; $P<0.05)$ and not in tilapia $(R-0.15, P>0.05)$. Finally, HOAD activity, a marker for fatty acid oxidation, was higher in trout (Fig. 2(G)) fed LPS compared to HPS diet, whereas no nutritional regulation of HOAD was seen in tilapia (Fig. 2(H)).

Regarding glucose phosphorylating enzymes (Fig. 3), starch-rich diets induced an increase in hepatic HK activity in both species (Fig. 3(A) and (B)). GK activity was only detected in trout (Fig. 3(C)) fed the starch-rich LPS diet and in all tilapia groups, except for those fed the low-starch/ high-fat diet HPF (Fig. 3(D)). In tilapia, the hepatic activity 
(A)

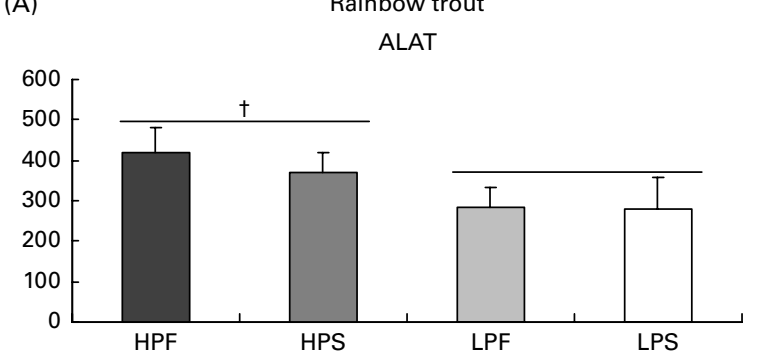

(C)

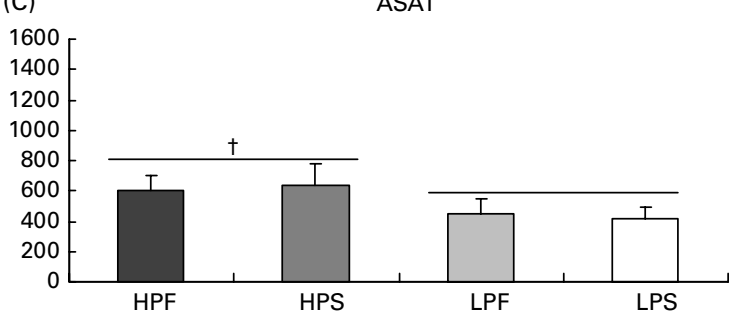

(E)

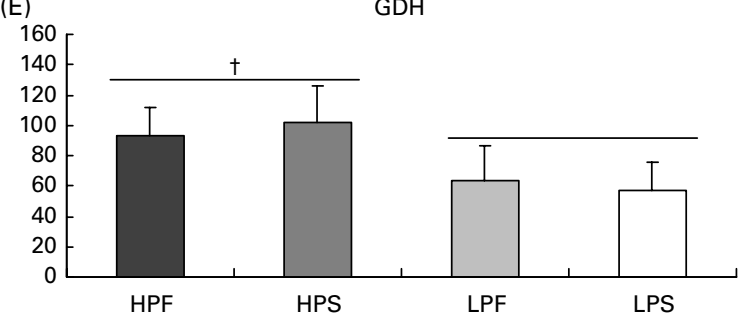

(B)
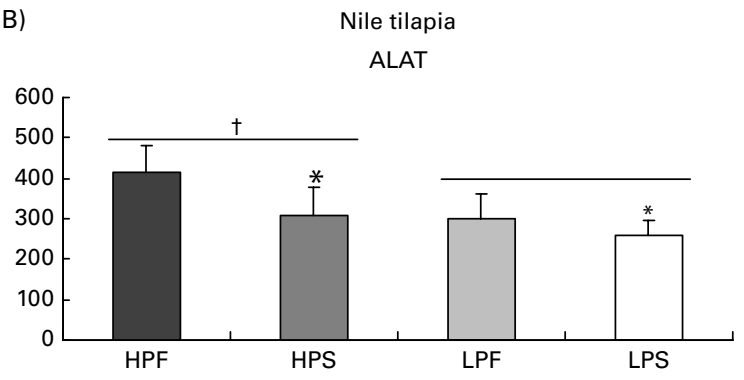

(D)

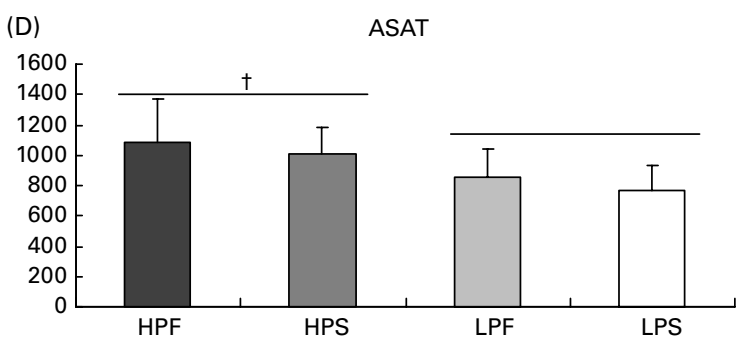

(F)

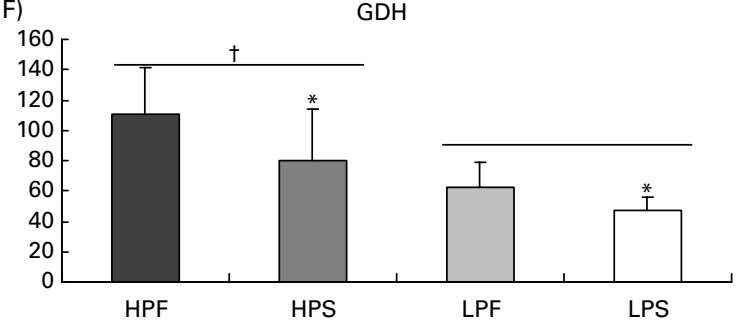

Fig. 1. Specific activities (mlU/mg protein) of two aminotransferases (alanine aminotransferase (ALAT) and aspartate aminotransferase (ASAT)) and of glutamate dehydrogenase $(\mathrm{GDH})$ deaminating enzyme in the liver of rainbow trout $(7 \mathrm{~h})$ and tilapia $(3 \mathrm{~h})$ fed with different digestible protein-to-energy (DP:DE) ratio and nonprotein energy source (NPE, fat $v$. starch). HPF, high protein with fat as the major NPE; HPS, high protein with starch as the major NPE; LPF, low protein with fat as the major NPE; LPS, low protein with starch as the major NPE. Values are means with standard deviations represented by vertical bars ( $n$ 9). Statistical significance for the two independent factors, DP:DE and NPE, and their interaction are as follows: (A) DP:DE, $P<0.01 ; \mathrm{NPE}, P=0.25 ; \mathrm{DP}: \mathrm{DE} \times \mathrm{NPE}, P=0.27 ;(\mathrm{B})$ DP:DE, $P<0.01$; NPE, $P<0.01$; DP:DE $\times$ NPE, $P=0.13$; (C) DP:DE, $P<0.01 ; \mathrm{NPE}, P=0.95 ; \mathrm{DP}: \mathrm{DE} \times \mathrm{NPE}, P=0.32 ;(\mathrm{D}) \mathrm{DP}: \mathrm{DE}, P<0.01 ; \mathrm{NPE}, P=0.25 ;$ $\mathrm{DP}: \mathrm{DE} \times \mathrm{NPE}, P=0.95$; (E) DP:DE, $P<0.01$; NPE, $P=0.86$; DP:DE $\times$ NPE, $P=0.30 ;(\mathrm{F}) \mathrm{DP}: \mathrm{DE}, P<0.01 ; \mathrm{NPE}, P<0.05 ; \mathrm{DP}: \mathrm{DE} \times \mathrm{NPE}, P=0.41$. ${ }^{*} \mathrm{Starch}-\mathrm{rich}$ diets were significantly different $(P<0.05)$ from fat-rich diets. †High-DP:DE diets differ significantly $(P<0.05)$ from low-DP:DE diets.

of G6Pase, a marker of glucose production, was the lowest with diet HPS (Fig. 3(F)), and did not correlate with the changing macronutrient intakes $(P>0.05)$. In trout (Fig. 3(E)), G6Pase activity was significantly higher when fed lowcompared to high-DP:DE diets and not affected by increasing amounts of dietary starch $(R-0 \cdot 15, P>0 \cdot 05)$.

\section{Discussion}

Rainbow trout and Nile tilapia have a similar optimal dietary DP:DE ratio of approximately $17-19 \mathrm{mg} / \mathrm{kJ}^{(1,30)}$ despite their different feeding habits (carnivorous $v$. omnivorous) and thermal preferendum (cold $v$. warm-water). In order to highlight possible metabolic mechanisms underlying the discrepancy in the response between both species to changes in macronutrient intakes, we kept the dietary DP:DE ratios well above $(27 \mathrm{mg} / \mathrm{kJ})$ or below $(14 \mathrm{mg} / \mathrm{kJ})$ both species' optimal DP:DE ratio. Tilapia and trout displayed a number of divergent responses to the dietary changes in DP:DE ratio and NPE source. These were related to growth, nutrient gains, nutrient utilisation efficiency (nutrient gain per unit digestible nutrient intake), plasma metabolite levels and with the activity of key enzymes involved in the intermediary metabolism in the liver of both species. The choice of sampling times ( 3 and $7 \mathrm{~h}$ after the meal, respectively, for tilapia and trout) was based on postprandial peak levels of metabolites in both species.

In both species, the replacement of fat by starch as the NPE source reduced the growth rate, although to a lesser extent in tilapia than in trout. This agrees with the literature that warmwater fish use more efficiently greater amounts of digestible carbohydrates (up to $40 \%$ ) than cold-water fish such as rainbow trout ${ }^{(10,23,24)}$. The high digestible fat level $(20 \%)$ in diet LPF did not negatively affect growth or protein utilisation in tilapia differing from reports of reduced growth in Nile tilapia fed dietary fat above $14 \%{ }^{(19)}$, but in line with the proteinsparing effect of dietary fat up to $18 \%$ in hybrid tilapia (Oreochromis mossambicus $\times$ Oreochromis niloticus) ${ }^{(37)}$. Our data on the response of tilapia to the two DP:DE levels show that tilapia handles well the storage/oxidation interplay of the high NPE load when fed low-protein diets containing approximately $280 \mathrm{~g} \mathrm{DP} / \mathrm{kg}$. A comparison of the efficiency of protein retention (per unit DP intake) between both species shows that this was improved at low relative to high DP:DE only when fat was used as the major NPE source in trout ${ }^{(31)}$ and independently of NPE source in tilapia ${ }^{(32)}$. This emphasises the importance of considering the type and not only 

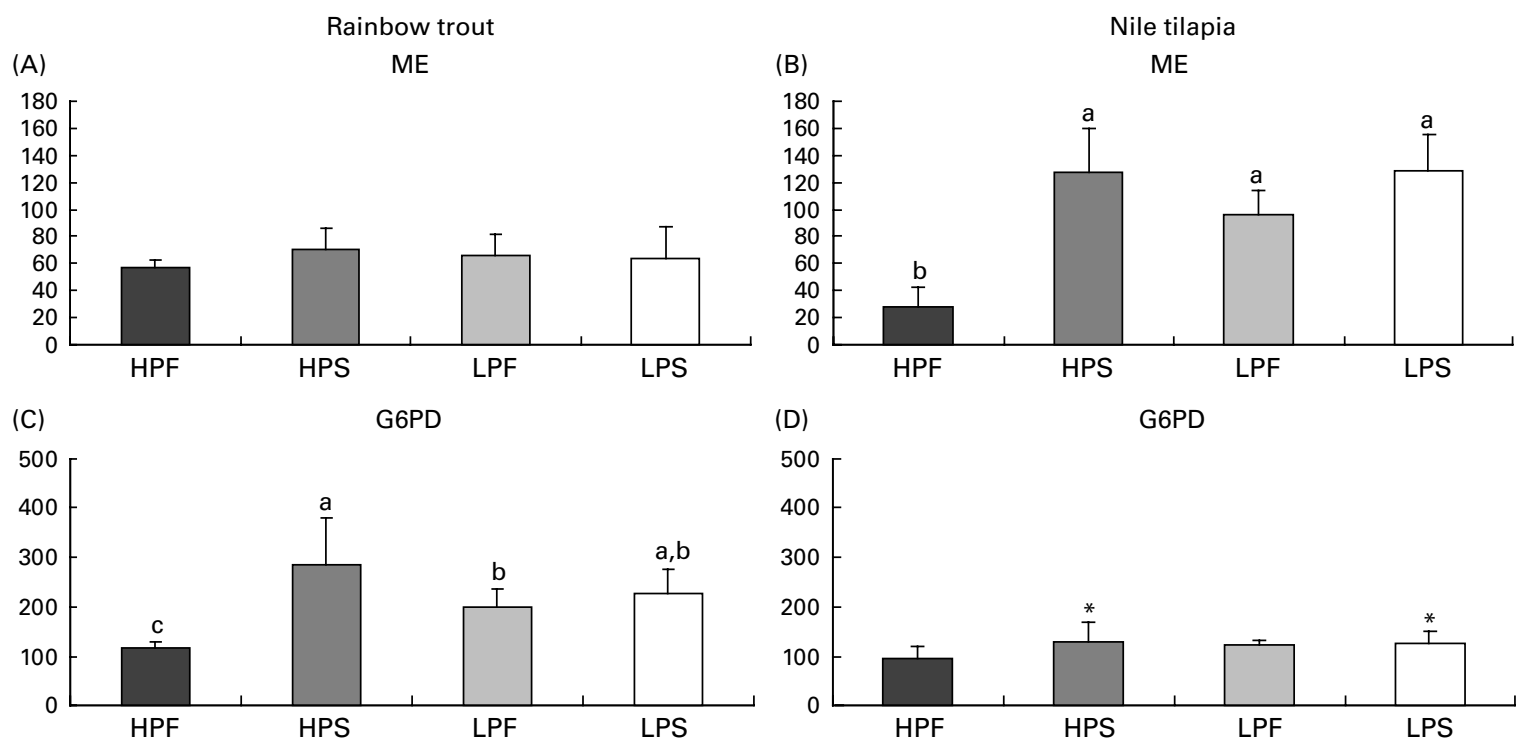

(D) G6PD
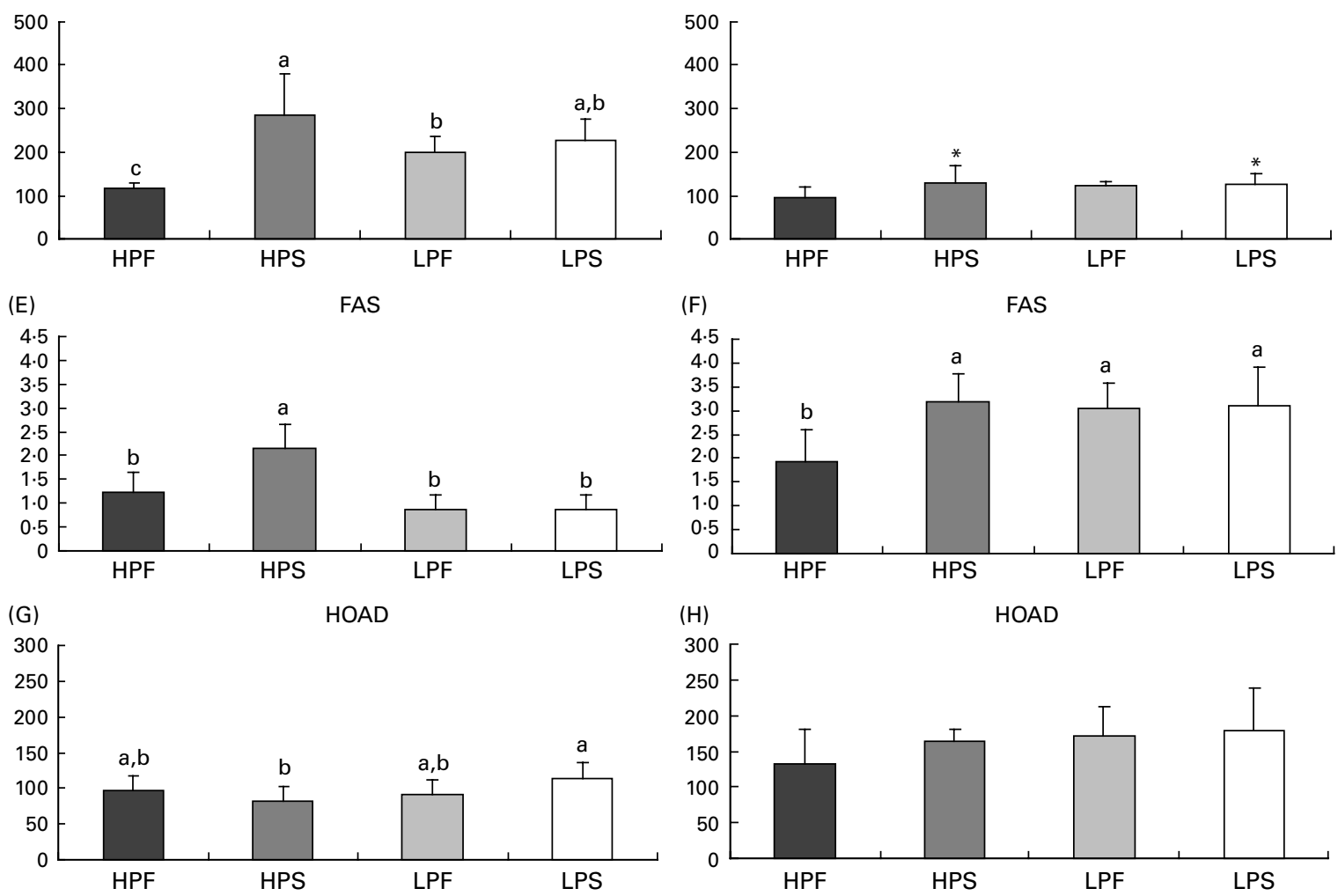

Fig. 2. Specific activities (mlU/mg protein) of lipogenic enzymes (malic enzyme (ME); glucose-6-phosphate dehydrogenase (G6PD) and fatty acid synthase (FAS)) and of 3-hydroxyacyl-CoA dehydrogenase (HOAD) in the liver of rainbow trout ( $7 \mathrm{~h}$ ) and tilapia $(3 \mathrm{~h})$ fed with different digestible protein-to-energy (DP:DE) ratio and non-protein energy source (NPE, fat $v$. starch). HPF, high protein with fat as the major NPE; HPS, high protein with starch as the major NPE; LPF, low protein with fat as the major NPE; LPS, low protein with starch as the major NPE. Values are means with standard deviations represented by vertical bars $(n 9)$. Statistical significance for the two independent factors, DP:DE and NPE, and their interaction are as follows: (A) DP:DE, $P=0.84 ; N P E, P=0.28 ; D P: D E \times N P E$, $P=0.21$; (B) DP:DE, $P<0.01$; NPE, $P<0.01$; DP:DE $\times$ NPE, $P<0.01$; (C) DP:DE, $P=0.50$; NPE, $P<0.01$; DP:DE $\times$ NPE, $P<0.01$; (D) DP:DE, $P=0.22$; NPE, $P<0.05$; DP:DE $\times$ NPE, $P=0.16$; (E) DP:DE, $P<0.01$; NPE, $P<0.01$; DP:DE $\times$ NPE, $P<0.01$; (F) DP:DE, $P<0.05 ; N P E, P<0.05 \mathrm{DP}: \mathrm{DE} \times \mathrm{NPE}, P<0.05 ;(\mathrm{G})$ $\mathrm{DP}: \mathrm{DE}, P=0.09$; NPE, $P=0.59$; DP:DE $\times$ NPE, $P<0.05$; (H) DP:DE, $P=0.08$; NPE, $P=0.22$; DP:DE $\times$ NPE, $P=0.38$. * Starch-rich diets were significantly different $(P<0.05)$ from fat-rich diets. In case of a significant interaction (DP:DE $\times$ NPE, $P<0.05)$, mean values lacking a common letter differ significantly.

the level of NPE in rainbow trout fed low-protein diets. Protein retention efficiency at high DP:DE was similar in both species and, moreover, independent of the NPE source. That NPE-induced changes in protein sparing are not discernible at protein intakes above requirement has been documented in several fish species, including rainbow trout $^{(38)}$ and tilapia ${ }^{(29)}$.

To our knowledge, this study is the first to undertake a comparative analysis of the enzymatic responses to changes in dietary DP:DE and NPE source in both species fed the same diets. Data on the relationship between diet-induced changes in protein utilisation and those in the hepatic activity level of enzymes involved in amino acid catabolism are contradictory. Previous studies reported that salmonids have little or no adaptation in activity of hepatic amino acid catabolising enzymes to variations in the amount of dietary protein supply ${ }^{(39,40)}$. In contrast, some other studies have shown a positive relationship between dietary protein intake and activity levels of transdeamination enzymes in tilapia ${ }^{(41)}$ as well as in rainbow trout ${ }^{(42)}$. Except for ASAT, the activity of which was higher in tilapia than in trout, we did not find any difference in ALAT and GDH specific activity levels between the two species. Moreover, reducing the protein supply (low $v$. high DP:DE) reduced the activity of the transdeamination enzymes in the liver of both species in a similar manner. These findings hence do not allow to explain the 
Rainbow trout

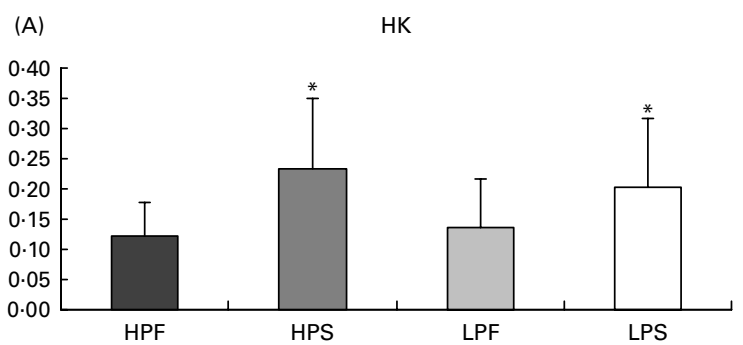

(C)

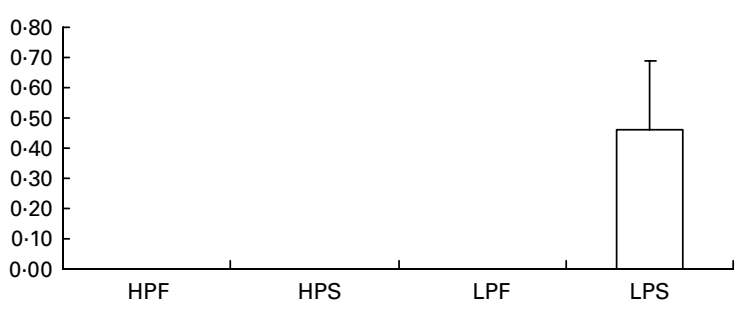

(E)

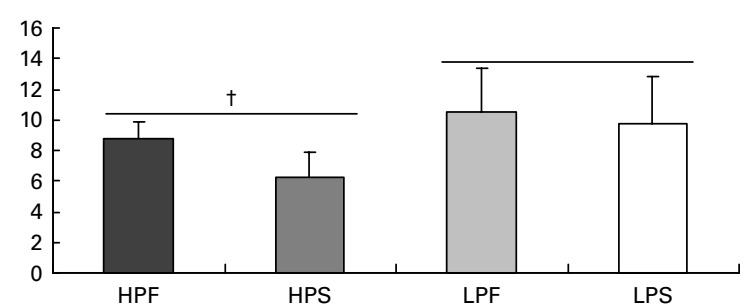

Nile tilapia

HK

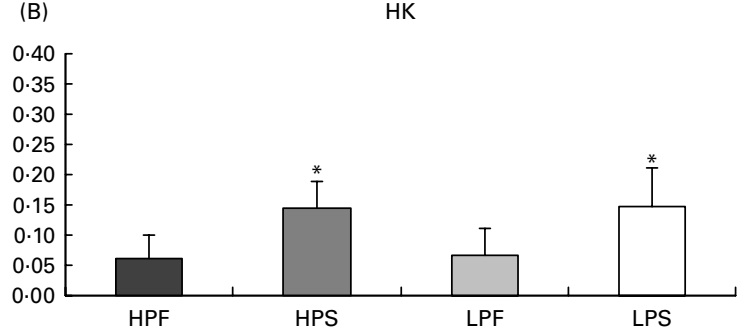

GK

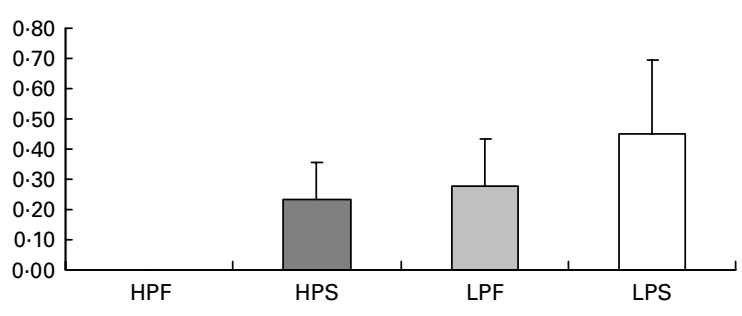

G6Pase

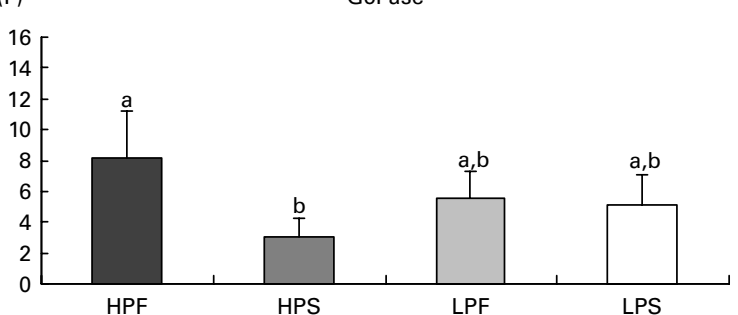

Fig. 3. Specific activities (mlU/mg protein) of glycolytic (hexokinase (HK) and glucokinase (GK)) and gluconeogenic (glucose-6-phosphatase (G6Pase)) enzymes in the liver of rainbow trout $(7 \mathrm{~h})$ and tilapia $(3 \mathrm{~h})$ fed with different digestible protein-to-energy (DP:DE) ratio and non-protein energy source (NPE, fat $v$. starch). HPF, high protein with fat as the major NPE; HPS, high protein with starch as the major NPE; LPF, low protein with fat as the major NPE; LPS, low protein with starch as the major NPE. Values are means with standard deviations represented by vertical bars $(n 9)$. Statistical significance for the two independent factors, $\mathrm{DP}: \mathrm{DE}$ and NPE, and their interaction are as follows: (A) DP:DE, $P=0.80$; NPE, $P<0.05$; DP:DE $\times$ NPE, $P=0.53$; (B) DP:DE, $P=0.86 ; \mathrm{NPE}, P<0.01 ; \mathrm{DP}: \mathrm{DE} \times$ NPE, $P=0.92$; (C) no statistical test; (D) no statistical test; (E) DP:DE, $P<0.01$; NPE, $P=0.05$; DP:DE $\times$ NPE, $P=0.25 ;(F)$ DP:DE, $P=0.73 ; N P E, P<0.01$; $\mathrm{DP}: \mathrm{DE} \times \mathrm{NPE}, P<0.01$. ${ }^{*}$ Starch-rich diets were significantly different $(P<0.05)$ from fat-rich diets. †High $\mathrm{DP}: \mathrm{DE}$ diets differ significantly $(P<0.05)$ from low$D P: D E$ diets. In case of a significant interaction (DP:DE $\times$ NPE, $P<0.05$ ), mean values lacking a common letter differ significantly.

lower protein retention efficiency in trout (34-44\%) compared to that in tilapia (58-59\%) at low DP:DE. Further, the response of the studied enzymes to changes in NPE source did not reflect the observed variations in protein retention efficiency. That fat constitutes a more efficient NPE source than starch in trout at low DP:DE (LPF $v$. LPS) was not reflected in differences in hepatic HOAD activity, a marker of mitochondrial fatty acid $\beta$-oxidation. The absence of nutritional regulation of HOAD activities in tilapia favours the idea that the energy provided by the supplementary lipid is preferentially directed towards storage in this species ${ }^{(16,18,19)}$ as reflected by the higher body fat deposition per unit protein accretion than in trout. The activity of FAS, used as a marker of lipogenesis, also showed a species-specific response to changes in dietary lipogenic substrates. At low DP:DE, hepatic FAS activity was low in trout and high in tilapia, suggesting a difference in the utilisation of the NPE source between both species at low protein intakes. Besides, the finding that the high FAS activity in tilapia was unaffected by the NPE source indicates either (i) the absence of a retro-inhibitory effect of the high fat content of diet (LPF) on lipogenic enzymes which contrasts with the inhibitory role of dietary fat on lipogenesis in tilapia ${ }^{(43)}$ as in other fish ${ }^{(3,44,45)}$, or (ii) an enhanced lipogenesis by the very high carbohydrate level (45\%) with diet LPS, in line with findings in other teleosts ${ }^{(3,4)}$ including rainbow trout ${ }^{(46)}$, or (iii) a combination of both, as diet LPF was rich in fat and starch. The enhanced lipogenic response of both species following the replacement of fat by starch at high DP:DE (diet HPS $v$. HPF) does not help to clarify the confounding role of lipid and carbohydrate on lipogenesis. Interestingly, the current data indicate species-specific differences in the dietary regulation of the pentose phosphate pathway (G6PD) and pyruvate-malate cycle (ME) as providers of NADPH reducing equivalents for lipogenesis. ME activity in trout liver was fairly low as already observed ${ }^{(30,47,48)}$ and unaffected by dietary factors, whereas G6PD activity, highly responsive to changes in macronutrient supply, paralleled that of FAS. In tilapia, the relative importance of G6PD and of ME activity varied considerably with diet composition, the latter being generally higher than that of G6PD. This does not fully comply with the overall higher activity of G6PD to that of ME reported in hybrid tilapia 
O. niloticus $\times$ Oreochromis aureus fed starch-rich $\operatorname{diets}{ }^{(49)}$, which in our study was only true with diet HPF.

Between-species comparison of plasma glucose in fish fed the low-DP:DE diets confirms the poor control of postprandial glycaemia in rainbow trout after oral administration of glucose or high-carbohydrate meals ${ }^{(25-27)}$. This is illustrated by the 2 to 3-fold higher plasma glucose in trout (1.9-4.6 g/1) compared to tilapia $(0.9-1.1 \mathrm{~g} / \mathrm{l})$ when fed diets with a low DP:DE ratio. Supplying different amounts of carbohydrates altered the activities of glucose-phosphorylating enzymes in a similar manner in both species, with GK (HK IV) activity being strongly enhanced by high carbohydrate intakes. A similar response and comparable activity levels in trout and tilapia were also seen for low-Km HK (HK I-III), reported as being little regulated by dietary factors in fish ${ }^{(12)}$. These similarities between species in the hepatic response and activity levels of GK and HK to changes in diet composition agree with findings from a previous study comparing glycolytic responses of trout and carp ${ }^{(28)}$. These data comply with the idea that the hepatic glycolytic potential itself does not explain the poor control of postprandial glycaemia in trout fed carbohydraterich diets ${ }^{(28,50)}$. The high glycaemia and low FAS activity levels observed here in trout (LPF $v$. LPS) is in conformity with our own recent data where we observed that hyperglycaemia in trout fed a diet rich in both starch and fat was associated with reduced hepatic lipogenesis ${ }^{(51)}$. Differences in hepatic lipogenesis have also been suggested to explain differences in glucose use among rainbow trout lines divergently selected for muscle fat content ${ }^{(52)}$. Likewise, the higher lipogenic capacity in tilapia compared to that in trout at low protein intakes suggests that, at similar hepatic glycolytic rates, the directing of carbohydrates towards lipogenesis in tilapia favoured the control of glycaemia in this species. At the same time, tilapia fed the low $v$. high DP:DE diets had reduced G6Pase activity, reflecting reduced gluconeogenesis. Persistent gluconeogenesis in trout fed starch-rich diets, reported to exacerbate hyperglycemia, has been attributed to the relatively high amount of protein in trout diets ${ }^{(34,35)}$, providing gluconeogenic (amino acids) substrates and/or promoting insulin resistance abolishing G6Pase inhibition as with mammalian type 2 diabetes ${ }^{(53)}$. However, our data of increased G6Pase activity in trout at low instead of high DP:DE do not support this hypothesis, requiring further consideration. Taken together, the hyperglycaemia in trout fed low-protein diets, as observed here and in some previous studies $^{(40,51)}$, probably results from the inability of rainbow trout to direct glucose towards lipogenesis and to reduce gluconeogenesis which probably relates with the low growth and low protein accretion in this species at suboptimal DP:DE.

In summary, the feeding of diets with varying DP:DE ratio and NPE source to both trout and tilapia shows speciesspecific differences in dietary macronutrient use, particularly evident at low DP:DE. The finding that only fat and not digestible starch improved protein utilisation efficiency at low DP:DE in trout further underlines the greater importance of the NPE source in this species than in tilapia. This study also reveals species-specific responses of enzymes involved in hepatic intermediary metabolism. The high lipogenic and reduced gluconeogenic capacity seem to contribute to the better use of carbohydrates and to the improved glycaemia control in tilapia compared with rainbow trout at low dietary DP:DE ratios.

\section{Acknowledgements}

The present study was funded by institutional INRA funds. A. C. F.-S. acknowledges the post-doctoral INRA fellowship (MRI, Package INRA-WUR Aquaculture Platform, Crédits CDD 9C). There are no conflicts of interest. The authors thank F. Terrier, F. Sandres and Y. Hontang (INRA Donzacq experimental fish farm), P. Aguirre and Y. Mercier (INRA St Pée sur Nivelle experimental rearing unit), E. Eding and M. ter Veld (Wageningen University, The Netherlands) for their technical assistance. The authors also thank A. Surget for the analyses of plasma total free amino acids. I. G., S. K., J. W. S., S. S. and A. C. F.-S. designed the research; S. S. conducted tilapia feeding trial and analysed growth and whole-body composition data; A. C. F.-S. performed the biochemical analyses, interpreted the results and wrote the manuscript together with I. G.; S. K., J. W. S. and S. P. contributed to the interpretation and presentation of the experimental data. All authors contributed to and approved the manuscript.

\section{References}

1. National Research Council (NRC) (2011) Nutritional Requirements of Fish and Shrimp. Washington, DC: The National Academies Press.

2. Wilson RP (2002) Amino acids and proteins. In Fish Nutrition, pp. 143-179 [JE Halver and RW Hardy, editors]. San Diego, CA: Academic Press.

3. Dias J, Alvarez MJ, Diez A, et al. (1998) Regulation of hepatic lipogenesis by dietary protein/energy in juvenile European seabass (Dicentrarchus labrax). Aquaculture 161, 169-186.

4. Fernández F, Miquel AG, Cordoba M, et al. (2007) Effects of diets with distinct protein-to-carbohydrate ratios on nutrient digestibility, growth performance, body composition and liver intermediary enzyme activities in gilthead sea bream (Sparus aurata, L.) fingerlings. J Exp Mar Biol Ecol 343, $1-10$.

5. Kaushik SJ \& Médale F (1994) Energy requirements, utilization and dietary supply to salmonids. Aquaculture 124, 81-97.

6. Kaushik SJ \& Oliva-Teles AD (1985) Effect of digestible energy on nitrogen and energy balance in rainbow trout. Aquaculture 50, 89-101.

7. Lee DJ \& Putnam GB (1973) The response of rainbow trout of varying protein-energy ratios in a test diet. J Nutr $\mathbf{1 0 3}$, 916-922.

8. Shiau SY \& Peng CY (1993) Protein sparing effect by carbohydrates in diets for tilapia, Oreochromis niloticus $\times O$. aureus. Aquaculture 117, 327-334.

9. Furuichi M \& Yone Y (1981) Change of blood sugar and plasma insulin levels of fishes in glucose tolerance test. Bull Jpn Soc Sci Fish 47, 761-764.

10. Wilson RP (1994) Utilization of dietary carbohydrate by fish. Aquaculture 124, 67-80. 
11. Hemre GI, Mommsen TP \& Krogdahl A (2002) Carbohydrates in fish nutrition: effects on growth, glucose metabolism and hepatic enzymes. Aquacult Nutr 8, 175-194.

12. Enes P, Panserat S, Kaushik S, et al. (2009) Nutritional regulation of hepatic glucose metabolism in fish. Fish Physiol Biochem 35, 519-539.

13. Sargent JR, Henderson RJ \& Tocher DR (1989) The lipids. In Fish Nutrition, pp. 152-218 [JE Halver, editor]. New York: Academic Press.

14. Cowey CB \& Sargent JR (1979) Nutrition. In Fish Physiology, pp. 1-69 [W Hoar, DJ Stewart, J Randall and R Brett, editors]. New York: Academic Press.

15. Watanabe $\mathrm{T}$ (1982) Lipid nutrition in fish. Comp Biochem Physiol 273B, 3-15.

16. Chou BS \& Shiau SY (1996) Optimal dietary lipid level for growth of juvenile hybrid tilapia, Oreochromis niloticus $\times$ Oreochromis aureus. Aquaculture 143, 185-195.

17. Lim C, Yildirim-Aksoy M \& Klesius P (2011) Lipid and fatty acid requirements of tilapias. North Am J Aquacult 73, 188-193.

18. Hanley F (1991) Effects of feeding supplementary diets containing varying levels of lipid on growth, food conversion, and body composition of Nile tilapia, Oreochromis niloticus (L.). Aquaculture 93, 323-334.

19. Ali A \& Al-Asgah NA (2001) Effect of feeding different carbohydrate to lipid ratios on the growth performance and body composition of Nile tilapia (Oreochromis niloticus) fingerlings. Anim Res 50, 91-100.

20. Du ZY, Clouet P, Zheng WH, et al. (2006) Biochemical hepatic alterations and body lipid composition in the herbivorous grass carp (Ctenopharyngodon idella) fed high-fat diets. Br J Nutr 95, 905-915.

21. Borges P, Oliveira B, Casal S, et al. (2009) Dietary lipid level affects growth performance and nutrient utilisation of Senegalese sole (Solea senegalensis) juveniles. Br J Nutr 102, $1007-1014$

22. Regost C, Arzel J, Cardinal M, et al. (2001) Dietary lipid level, hepatic lipogenesis and flesh quality in turbot (Psetta maxima). Aquaculture 193, 291-309.

23. Shiau SY (1997) Utilization of carbohydrates in warmwater fish - with particular reference to tilapia, Oreochromis niloticus $\times$ O. aureus. Aquaculture 151, 79-96.

24. Wang Y, Liu YJ, Tian LX, et al. (2005) Effects of dietary carbohydrate level on growth and body composition of juvenile tilapia, Oreochromis niloticus $\times O$. aureus. Aquacult Res 36, 1408-1413.

25. Bergot F (1979) Effects of dietary carbohydrates and their mode of distribution on glycemia in rainbow trout (Salmo gairdneri Richardson). Comp Biochem Physiol 64A, 543-547.

26. Brauge C, Médale F \& Corraze G (1994) Effect of dietary carbohydrate levels on growth, body composition and glycemia in rainbow trout, Oncorbynchus mykiss, reared in seawater. Aquaculture 123, 109-120.

27. Palmer TN \& Ryman BE (1972) Studies on oral glucose intolerance in fish. J Fish Biol 4, 311-319.

28. Panserat S, Médale F, Blin C, et al. (2000) Hepatic glucokinase is induced by dietary carbohydrates in rainbow trout, gilthead seabream, and common carp. Am J Physiol Regul Integr Comp Physiol 278, R1164-R1170.

29. Kaushik SJ, Doudet T, Médale F, et al. (1995) Protein and energy needs for maintenance and growth of Nile tilapia (Oreochromis niloticus). J App Ichthyol 11, 290-296.

30. Dias J, Corraze G, Arzel J, et al. (1999) Nutritional control of lipid deposition in rainbow trout and European seabass: effect of dietary protein energy ratio. Cybium $\mathbf{2 3}$, $127-137$

31. Saravanan S, Schrama JW, Figueiredo-Silva AC, et al. (2012) Constraints on energy intake in fish: the link between diet composition, energy metabolism and energy intake in rainbow trout. PlosOne 7, e34743.

32. Saravanan S, Geurden I, Figueiredo-Silva AC, et al. (2012) Control of voluntary feed intake in fish: a role for dietary oxygen demand in Nile tilapia (Oreochromis niloticus) fed diets with different macronutrient profiles. Br J Nutr (Epublication ahead of print version 6 January 2012)

33. Figueiredo-Silva AC, Corraze G, Kaushik S, et al. (2010) Modulation of blackspot seabream (Pagellus bogaraveo) intermediary metabolic pathways by dispensable amino acids. Amino Acids 39, 1401-1416.

34. Panserat S, Capilla E, Gutierrez J, et al. (2001) Glucokinase is highly induced and glucose-6-phosphatase poorly repressed in liver of rainbow trout (Oncorbynchus mykiss) by a single meal with glucose. Comp Biochem Physiol 128B, 275-283.

35. Panserat S, Médale F, Breque J, et al. (2000) Lack of significant long-term effect of dietary carbohydrates on hepatic glucose-6-phosphatase expression in rainbow trout (Oncorbynchus mykiss). J Nutr Biochem 11, 22-29.

36. Figueiredo-Silva AC, Kaushik S, Terrier F, et al. (2012) Link between lipid metabolism and voluntary food intake in rainbow trout fed coconut oil rich in medium-chain TAG. Br J Nutr 107, 1714-1725.

37. De Silva SS, Gunasekera RM \& Shim KF (1991) Interactions of varying dietary protein and lipid levels in young red tilapia: evidence of protein sparing. Aquaculture $\mathbf{9 5}$ 305-318

38. Geurden I, Gondouin E, Rimbach M, et al. (2006) The evaluation of energy intake adjustments and preferences in juvenile rainbow trout fed increasing amounts of lipid. Physiol Behav 88, 325-332.

39. Cowey CB \& Walton MJ (1989) Intermediary metabolism. In Fish Nutrition, pp. 259-329 [JE Halver, editor]. New York: Academic Press.

40. Kirchner S, Kaushik S \& Panserat S (2003) Low protein intake is associated with reduced hepatic gluconeogenic enzyme expression in rainbow trout (Oncorbynchus mykiss). J Nutr 133, 2561-2564.

41. Gaye-Siessegger J, Focken U \& Becker K (2006) Effect of dietary protein/carbohydrate ratio on activities of hepatic enzymes involved in the amino acid metabolism of Nile tilapia, Oreochromis niloticus (L.). Fish Physiol Biochem 32 275-282.

42. Lupianez JA, Sanchezlozano MJ, Garciarejon L, et al. (1989) Long-term effect of a high protein non-carbohydrate diet on the primary liver and kidney metabolism in rainbow trout (Salmo gairdneri). Aquaculture 79, 91-101.

43. Gaye-Siessegger J, Focken U, Abel H, et al. (2004) Dietary lipid content influences the activity of lipogenic enzymes in the liver and on whole body delta C-13 values of Nile tilapia, Oreochromis niloticus (L.). Isotopes Environ Health $S \mathbf{4 0}$, 181-190.

44. Gélineau A, Corraze G, Boujard T, et al. (2001) Relation between dietary lipid level and voluntary feed intake, growth, nutrient gain, lipid deposition and hepatic lipogenesis in rainbow trout. Reprod Nutr Dev 41, 487-503.

45. Likimani TA \& Wilson RP (1982) Effects of diet on lipogenic enzyme activities in channel catfish hepatic and adipose tissue. J Nutr 112, 112-117.

46. Brauge C, Corraze G \& Médale F (1995) Effects of dietary levels of carbohydrate and lipid on glucose oxidation and 
lipogenesis from glucose in rainbow trout, Oncorbynchus mykiss, reared in fresh water or in seawater. Comp Biochem Physiol 111A, 117-124.

47. Barroso JB, García-Salguero L, Peragon J, et al. (1994) The influence of dietary protein on the kinetics of NADPH production systems in various tissues of rainbow trout (Oncorbynchus mykiss). Aquaculture 124, 47-59.

48. Walzem RL, Storebakken T, Hung SSO, et al. (1991) Relationship between growth and selected liver enzyme activities of individual rainbow trout. J Nutr 121, 1090-1098.

49. Lin JS \& Shiau SY (1995) Hepatic enzyme adaptation to different dietary carbohydrates in juvenile tilapia Oreochromis niloticus $\times$ Oreochromis aureus. Fish Physiol Biochem 14, 165-170.
50. Panserat S, Perrin A \& Kaushik S (2002) High dietary lipids induce liver glucose-6-phosphatase expression in rainbow trout (Oncorbynchus mykiss). J Nutr 132, 137-141.

51. Figueiredo-Silva AC, Panserat S, Kaushik S, et al. (2012) High levels of dietary fat impair glucose homeostasis in rainbow trout. J Exp Biol 215, 169-178.

52. Skiba-Cassy S, Lansard M, Panserat S, et al. (2009) Rainbow trout genetically selected for greater muscle fat content display increased activation of liver TOR signaling and lipogenic gene expression. Am J Physiol Regul Integr Comp Physiol 297, R1421-R1429.

53. Tremblay F, Lavigne C, Jacques H, et al. (2007) Role of dietary proteins and amino acids in the pathogenesis of insulin resistance. Annu Rev Nutr 27, 293-310. 